\title{
The Effect on Entrepreneurship Subject towards Entrepreneurship Interest for Tourism Higher Education Students
}

\author{
Lestari Ningrum $^{1}$, NovitaWidyastuti ${ }^{2}$ and Filma Festivalia ${ }^{3}$ \\ ${ }^{1,2,3}$ Sekolah Tinggi Pariwisata Trisakti, Jakarta, Indonesia
}

Email: ${ }^{1}$ lestariningrum@ stptrisakti.ac.id, ${ }^{2}$ novita.ws@ stptrisakti.ac.id and ${ }^{3}$ FFFestivalia_06@yahoo.co.id

\begin{abstract}
Entrepreneurship education holds significant role in fostering the growth of entrepreneurship in Indonesia. However, little attention is given to access its impact. This study aims to examine the effect of entrepreneurship education on students' entrepreneurial interests in Tourism Higher Institution. This research would like to find out whether the entrepreneurship education affects the students's interest in becoming an entrepreneur in the future. This is essential since tourism higher institutions not only prepare the students to work in hospitality industry, but they are also equipped with skills to start a business. The methodology of the research included survey based on the questionnaires carried out in Campuss STP Trisakti. A correlation descriptive research method is employed. Slovin formula is used to determine the number of sample with 186 respondents. Besides, reliability, validity, statistical descriptive, correlation and simple linear test are also employed. The results reveals that students of Trisakti School of Tourism are highly affected by the content presented in entrepreneurship education, and it is able to inspire both their attitudes and behaviors in entrepreneurship, while their entrepreneurship intention is very high, with an average value of 3.5 up to 3.6. The result of the positive and linear relationship between entrepreneurship education and entrepreneurship interest in the Trisakti School of Tourism is in medium (0.526), and entrepreneurship interest is influenced by entrepreneurship subject $\mathbf{2 7 . 7 \%}$. It means that students are interested to start a business after they graduate from college.
\end{abstract}

Keywords-Education, Entrepreneurship Course

\section{INTRODUCTION}

At present, university graduates are facing limited employment in some big cities in Indonesia. These college graduates are prone to be educated unemployment. According to The Central Bureau of Statistics (BPS), the number of open unemployment in 2016 reaches 7.024 millionpeople and investigations showThis Unemployment generally occurs because the number of the workforce is not in balance with the number of job opportunities, they prefer to work inafirmthan to start their own business as enterpreneur.To solve the problem of unskilled unemployment, The Ministry of Cooperatives and UKMs (small and medium enterprises) continue to give encouragement and motivation to young people such as students to have the spirit of entrepreneurship.

One of the government efforts is to issue several policy packages, namely establishing an entrepreneurship consultation clinic facility and business incubator development undertaken by the Ministry of Cooperatives and UKMs. This is conducted by inviting all elements of society, especially academia, business and government to encourage youth for entrepreneurship training programs and Capital assistance for entrepreneurs soft loan with a maximum value of Rp 25 million, Partnership and Community Development Program and Financing Program from Private Companies as part of their Corporate Social Responsibility (CSR) programe, (Soepardi,2015).

Deputy Human Resources (HR) Kemenkop and UKM, Prakoso BS said, "Young people actually have the desire and ideas for entrepreneurship, but had not the courage" (Kompas.com, January 11,2017), College and college graduates need to change the mindset that after graduation is not looking for work job but creating a job. Data Kemenkop UKM shows, currently the number of 
entrepreneurs in Indonesia only reached 1.65 percent or about 3.7 million. Which actualy to become a developed country, the number of entrepreneurs at least should be two percent of the total population. Indonesia which has population of 252 million, required 4.8 million entrepreneurs.

Compared to other countries, In United States, more than 12 percent of the population became entrepreneurs, in every 11 seconds, a new entrepreneurs has arisen and the data shows 1 in 12 Americans is directly involved in entrepreneur activities. In Japan more than 10 percent of the population is entrepreneurs in 240 small, medium and large Japanese companies. Though Japan has a very small area and less supportive natural resources (less fertile) but with enthusiasm and spirit of entrepreneurship, Japan is now the richest country in Asia. More than 7.2 percent of Singapore population are entrepreneurs and more than 3 percent of Malaysian entrepreneurs are making growth in various fields, especially economic growth, further leaving Indonesia.

The role of universities is also important in motivating entrepreneurship interests, Suharti (2012), stating that one of the actors driving entrepreneurial growth in a country lies in the role of the university through the implementation of entrepreneurship education. The university is responsible for educating and giving entrepreneurship skills and motivating the Student to dare to choose entrepreneur as their career.

As a sample one college in the United States, namely MIT (Massachusette Institute Technology) in the period of 1980-1996 amid the increasingly widespread educated unemployment and economic, socio-political conditions that are less stable, MIT change the direction of college policy of high Learning Institute and Research University became Entrepreneurial University. This new mindset are also follow by other University such as UI, UNDIP, ITB, UNPAD, IPB, UGM, etc . Trisakti School of Tourismas one of the leading tourism higher education in Indonesia, emphasizes Entrepreneurship Priority as well, which is now in preparation to be include in curriculum.

\section{LITERATURE REVIEW}

Entrepreneurship is a discipline that studies values, abilities and behaviors in facing life's challenges. The transformation of entrepreneurial knowledge has developed in recent years.

Lestari et al.(2012:1) states that entrepreneurship education can shape the mindset, attitude, and behavior of students into a true entrepreneur thus directing them to choose entrepreneurship as a career choice. Entrepreneurship learning method must be able to transfer not only knowledge and skill but also ability to realize a real effortand earn soul from entrepreneurship itself (Siswadi,2013).

Entrepreneurship education is highly dependent on acceptance of entrepreneurial mindset in universities and the creation of entrepreneurial environments in and around the University (Varblane et al.,2010).

Brown, 2000 in Izedonmi, (2010:10), states that entrepreneurial education is designed to communicate and inculcate competencies, skills and values are needed to recognize business opportunities, organize and start new business ventures. Entrepreneurship learning in universities refers to Presidential Regulation No. 6 of 2009 states as follows: The Ministry ofEducation and Culture through the Directorate General of Secondary Education and the Directorate General of Higher Education has implemented entrepreneurship education as a concrete manifestation to foster creative, innovative, sportive and entrepreneurial spirit In educational methodology as the elaboration of Creative Economic Development.

Ahmadi (2009:148) in Darmawan, 2015 says that "interest is the attitude of one's soul including the three functions of his soul (cognition, conjunction, and emotion), which is fixed on something and in that relationship a strong element of feeling". Meanwhile, according to Djaali (2008: 121) "interest is a sense of preferences and a sense of interest in a thing or activity, without anyone telling". Meanwhile, according to Crow \& crow in Djaali, said that "interest is related to the style of motion that encourages a person to deal with or deal with people, objects, activities, experiences stimulated by the activity itself".

Interest in one's entrepreneurship can be seen from three main indicators in research (Hattab, 2014: 5), namely:

1. Personal Attitude

Personal attitudes are individual beliefs about the outcome of a behavior. Attitudes 
towardbehavior are influenced by the belief that the behavior will lead to desired or undesirable outcomes. Individuals who have positive beliefs about a behavior will have a tendency to do such actions.

\section{Subjective Norms}

A person's belief or perception of the social influences or expectations of those around him about what should and should not be done. If the individual believes in the norms of his or her social group, he will obey and shape appropriate behavior with his group.

3. Perceived behavior control (control perceived behavior)

Behavioral control is a belief about the presence or absence of factors that hinder the behavior of individuals. In other words, behavior control is a belief about the existence of things that are able to support or inhibit their behavior. Behavior control is very important when a person's confidence is in a weak condition.

\section{METHODS}

In this research, a descriptive correlational research is employed to explain the relationship between two variables that is independent variable with dependent variable (Notoatmodjo, 2012: 14). Likert scale, then the variables to be measured are translated into variable indicators (Eko Putro Widoyoko: 2012). In Likert scale, there are 4 (four) scales /alternative answer choices. The four scales consist of Strongly Agree (SS), Agree (S), Disagree (TS), and Strongly Disagree (STS). Here is a table that describes the scores on each likert scale.

The population of this research is 349 students of Trisakti School of Tourism especially majoring in hospitality class of 2013 which have taken entrepreneurship subject. Based on Slovin formula Sevilla (2007), the number of sampling are 186 respondents. Reliability test, validity test, statistical descriptive test, correlation test and regression test are employed. To interpret the statistical descriptive test in the form of mean result, through theory and formula developed by Sugiyono, 2014: 49, the level of interval value is as follows:

TABLE I. VARIABLE INTREPRETATION

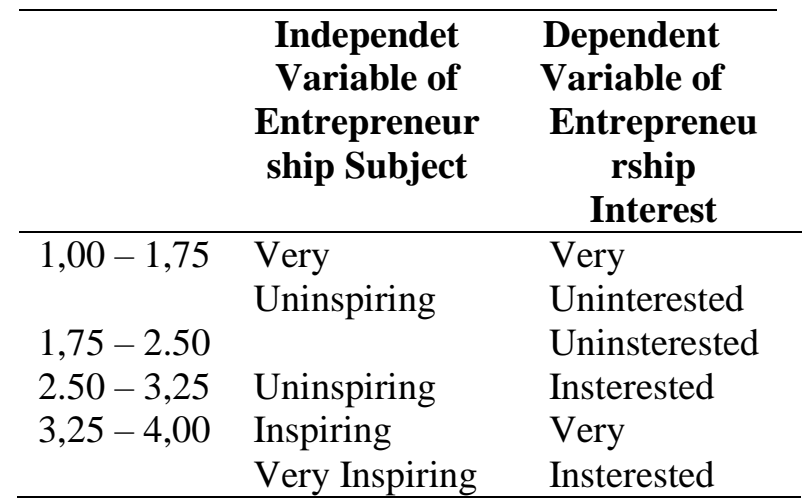

\section{RESULT AND DISCUSSION}

\section{TABLE II. RELIABILITY STATISTICS}

\begin{tabular}{cc}
\multicolumn{2}{c}{ Reliability Statistics } \\
\hline $\begin{array}{c}\text { Cronbach's } \\
\text { Alpha }\end{array}$ & N of Items \\
\hline, 898 & 15
\end{tabular}

Based on the results of reliability testing in table 4.1 and 4.2 above with 186 respondents, it can be concluded that the statement given to the respondents in this study is reliable because cronbach's alpha of each variable higher than 0.6 , meaning to 186 respondents managed to answer consistently to 
the 15 instruments of the proposed statement. And the statements submitted in the questionnaire to the respondent are valid because $r$ count on each of the statements in this study is higher than $r$ table (0.121).

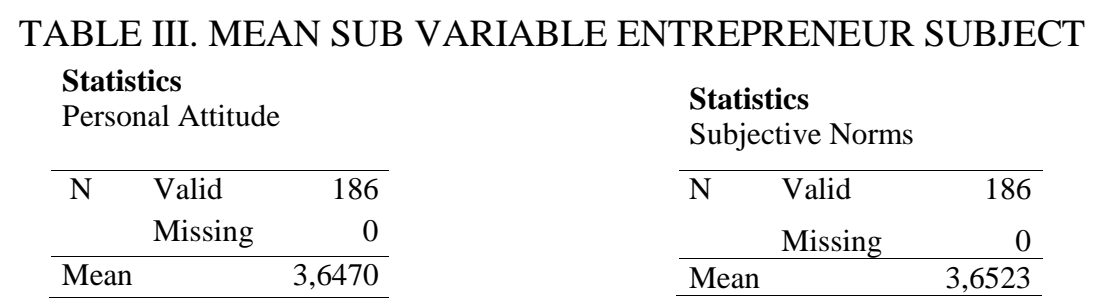

It is known that the above average value is the average value of each sub variable of a variable from the questionnaire that has been disseminated to the respondent. With the independent variable is Entrepreneurship Subject obtained the highest average value is on Attitude with a value of 3,5520 which is related to the result that "respondents have changed the attitude of confidence and after following the Entrepreneurship Subject, and they are very inspired by entrepreneurship subject".

While the average value for the Mindset obtained value 3.5341 which is related to the respondent's statement that by following the entrepreneurial subject of mind focused and inspired on the job as an entrepreneur. So it can be concluded that the inspiration in following the highest entrepreneurship subject happened to the respondent is Attitude. And with the average value of attitude with a value of 3,5520, entrepreneurship subjects are very inspiring attitudes of students and entrepreneurship mindset.

\section{TABLE IV. MEAN SUB VARIABLE ENTREPRENEUR SUBJECTS}

Statistics
Personal Attitude
\begin{tabular}{lll}
$\mathrm{N} \quad$ Valid & 186 \\
& Missing & 0 \\
\hline Mean & 3,6470 \\
\hline
\end{tabular}

\begin{tabular}{|c|c|c|}
\hline \multicolumn{3}{|c|}{$\begin{array}{l}\text { Statistics } \\
\text { Subjective Norms }\end{array}$} \\
\hline \multirow[t]{2}{*}{$\mathrm{N}$} & Valid & 186 \\
\hline & Missing & 0 \\
\hline & & 3,6523 \\
\hline
\end{tabular}

Statistics

Perceived Behavioural Control

\begin{tabular}{lll}
\hline $\mathrm{N}$ & Valid & 186 \\
& Missing & 0 \\
\hline Mean & & 3,5806
\end{tabular}

It is known that the above average value is the average value of each sub variable of a variable from the questionnaire that has been disseminated to the respondent. With the "Y" variable Interest in Entrepreneurship obtained the highest average value of Subjective Norms with a value of 3.6523 which is related to the statement that "After studying entrepreneurship, respondents can provide jobs for otherand studying entrepreneurship can make the respondents interested in becoming an entrepreneur".

In Personal Attitude, related to the statement of beliefs to be successful young entrepreneurs, the intention to start a business after graduation, the understanding to become a successful entrepreneur must work hard, illustrates that they are very interested in doing business than working with others.

The average value on Perceived behavior control is 3.5806 which is related to the result to "Respondents are interested to become an entrepreneur since they believe that theywill succeed in their business "the ability that will succeed in entrepreneurship describes they are also very interested in entrepreneurship because it has a picture of the future will be their success". So it can be concluded that the most frequent changes in respondents are Subjective Norms. With the average value of Subjective Norms with a value of 3.6523 then the results can be said entrepreneurial subjects are very inspiring.

Entrepreneurship is presented in the form of theory and practice. In theory, it mostly discusses on the understanding of entrepreneurship from various sources, the character of an entrepreneur, the types of entrepreneurship, knowledge on UMKM (Micro, Small and Medium Enterprises), creative and innovative thinking (as well as workshops to make products from household waste), business ideas creation, business risks identification, business plans creation, product design development for business plans and in the last session, students must promote, introduce and sell their products at the Entrepreneurship Expo event.

Assessment begins as the students create projects consisting of planning business plans, starting 
up business and product design (in the form of task assignments and task presentations) and ultimately approved products in accordance with the business plan shown on Entrepreneur Expo. The sales report on entrepreneurship expo was assessed to be in conformity with the business plan that had been arranged before.

\section{TABLE V. MEAN SUB VARIABLE INTEREST IN ENTREPRENEUR}

\begin{tabular}{|c|c|c|}
\hline & $\begin{array}{l}\text { tistics } \\
\text { sonal Att }\end{array}$ & ude \\
\hline $\mathrm{N}$ & Valid & 186 \\
\hline & Missing & 0 \\
\hline & & 3,6470 \\
\hline
\end{tabular}

\begin{tabular}{|c|c|c|}
\hline $\begin{array}{l}\text { Stat } \\
\text { Sub }\end{array}$ & $\begin{array}{l}\text { istics } \\
\text { jective No }\end{array}$ & \\
\hline $\mathrm{N}$ & Valid & 186 \\
\hline & Missing & 0 \\
\hline $\mathrm{Me}$ & &, 6523 \\
\hline
\end{tabular}

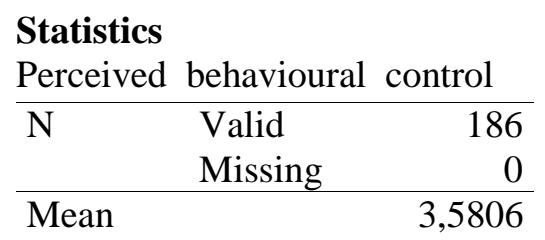

With the variable $\mathrm{Y}$ that Interest in Entrepreneurship obtained the highest average value is the Subjective Norms with a value of 3.6523 which is related to the sresult that "respondents with entrepreneurship can create jobs for others."While the lowest average value obtained on Perceived behavior control with a value of 3,5806 which is related to the respondent's statement of "the ability that will succeed in entrepreneurship".

So it can be concluded that the most frequent changes in respondents are Subjective Norms and from the interval scale, with an average value of Subjective Norms, personal Attitude and Perceived behavior control with values between 3.5 to 3.6 then the result can be said to be very interested to entrepreneurship.

TABLE VI. RESULT OF MEAN VARIABLE

\begin{tabular}{llcc}
\hline & & $\begin{array}{c}\text { Entrepreneurship } \\
\text { Subject }\end{array}$ & $\begin{array}{c}\text { Entrepreneurship } \\
\text { Interest }\end{array}$ \\
\hline $\mathrm{N} \quad$ Valid & 186 & 186 \\
& Missing & 0 & 0 \\
Mean & 3,5520 & 3,5806 \\
\hline
\end{tabular}

The average value of these two research variables has values in the same interval level. So it can be concluded that entrepreneurship courses for the respondents are very inspiring them, while entrepreneurial interest of the respondents in high level/very interested.

TABLE VII. CORRELATION BETWEEN ENTREPRENEUR SUBJECT AND INTEREST IN ENTREPRENEUR

\begin{tabular}{llcc}
\hline & & $\begin{array}{c}\text { Entrepreneur } \\
\text { Subject }\end{array}$ & $\begin{array}{c}\text { Interest in } \\
\text { Entrepreneur }\end{array}$ \\
\hline $\mathrm{X}$ & Pearson & 1 &, $526^{* *}$ \\
& Correlation & & \\
& Sig. (2-tailed) & &, 000 \\
& N & 186 & 186 \\
Y & Pearson &, $526^{* *}$ & 1 \\
& Correlation & & \\
& Sig. (2-tailed) &, 000 & 186 \\
N & 186 & 186 \\
\hline
\end{tabular}

In it is stated that there is a positive relationship between entrepreneurship subject and entrepreneurship interest presented by correlation coefficient $r=0,526$, this nominal indicates that there is correlation of "medium" between the two variables, it can also be interpreted that students are interested in entrepreneurshipbut the subject is only able to attract students in a moderate level.

The lack of entrepreneurial subject influences entrepreneurial interests, because of some reasons, that some students who take part entrepreneurship subject is interested in the materials and practices taught, but they will not set up business yet, some students will still seek work experience in the industry for example from both hotel and cruise for the provision of science practices that will be 
useful if they are become entrepreneur.

Students are also very interested in the process they have to accomplish before they run a project. The students think that the process will help to evaluate their effortsin the future when they start a business.

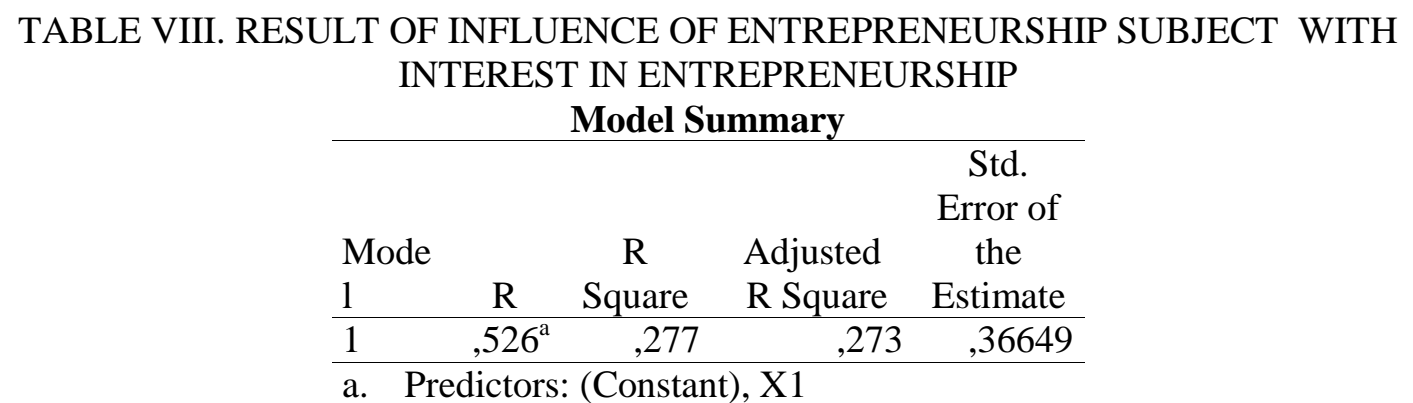

Interest in entrepreneurship influenced entrepreneurship subjects by $27.7 \%$, the rest in influencing other variables, which can be proposed for further research may be influenced by field work practices, other campus practice lessons that have not been studied in this study.

Results of positive and linear regression direction, where if the entrepreneurship subject is in demand then entrepreneurship interest will be high as well, this is happening in the results of this study entrepreneurship subjects attracted high interest for entrepreneurship.

\section{DISCUSSION}

The value of the entrepreneurship subject was variables, it can provide high inspiration to the students can be attributed during the lecture of the students in their skills, for example capability to selection of materials, especially the use of secondhand materials.

This process aims to train their mental to not always prioritize money for business capital. Besides, they have to discuss with thegroup on how to create a good product, and how to make an interesting and affordable product. Finally, they have to prove themselves that the products are worthy of sale, as seen in the figure below:



Source : Private collection

FIG I. PREPARE

ACTIVITIES OF MAKING WORKS USED MATERIALS

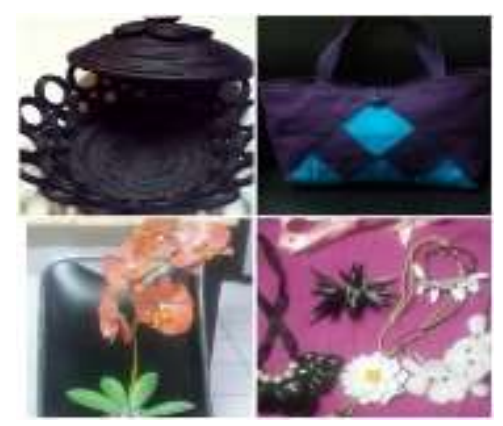

Source : Private collection FIG II. PRODUCTS FROM USED MATERIALS

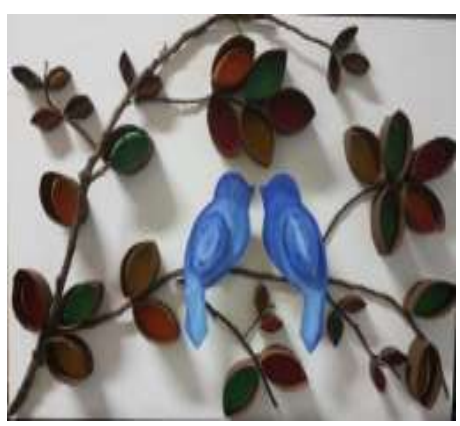

Source : Private collection FIG III. WALL HANGINGS FROM PAPER ROLL TISSUE

The result shows the Student very high interest of entrepreneurship. With knowledge and practice in making a small scale business project, they are trained to do the planning in determining the product to be made and sold, selection raw material, budgets arrangement, food cost calculations, profit-loss considerations, marketing strategies, designing logos, good packaging, and product pricing. This is a challenging them to prove the best product and they must present their results whether they meet the targets or not.

This is in accordance with Herawati's research (2011) stating that many steps can be done in entrepreneurship by doing research continuously to develop the business, producing products or services that consumers demand, determine the right price in accordance with the quality of products 
or services, determine Proper distribution of products or services producedand finally how to introduce products or services produced.

Given that the relationship between the variables of entrepreneurship subjects and interest in entrepreneurship are "moderate", when referring to the data, where respondents were not working (students) of $42.5 \%$, with $42.5 \%$ of students in the data last year have not worked.Then the "medium" relationship reflects that entrepreneurial interest already exists in the students but not yet thoroughly proved by $42.5 \%$ of students in their final year of study, has not worked yet.

Trisakti School of Tourism's students are claimsthey are moreconfident to do business after they jointhe entrepreneurship subject, it is possible because in the course the students are given the opportunity to decide the project they will run as their group pilot project. The type of business most widely chosen is a culinary business considering the suitability of the majors they choose. To create a business project, they are trained to do the process from the beginning, namely good planning of the determination of the menu, food cost, selling price, promotion strategies to the determination of break even point and profit targets, their confidence will grow by itself because it has gained knowledge in the field.

The influence of entrepreneurship subject to entrepreneurship interest is still low (27.7\%), whereas data from the mean value indicates that the courses inspire them greatly and interest in entrepreneurship is also high. This can be resulted from several factors, such as mental readiness to do business especially for the youth who have never done a business at all. Mental readiness in entrepreneurship is the most important part. Even business capital for the moment is no longer the most important thing or no longer prioritized regarding to the fact that there are some businesses with limited or even without any capital at all.

Mental readiness can not only be obtained from the course, but it can be obtained further from the life process, the process of success and failure that in life and business, the process of overcoming any existing problems both in life and in running a business, such as parental advice; the more we experience in the fluctuating life process the more we become rich with experience.

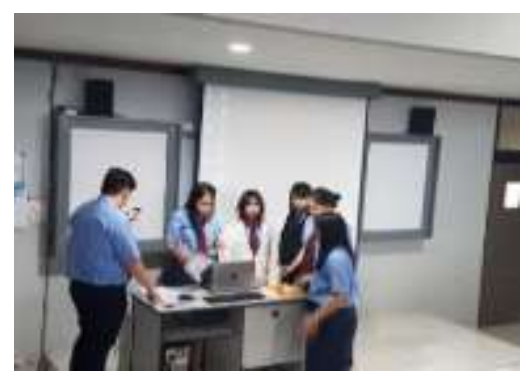

Source : Private Collection

Fig IV. Preparing for culinery project presentation

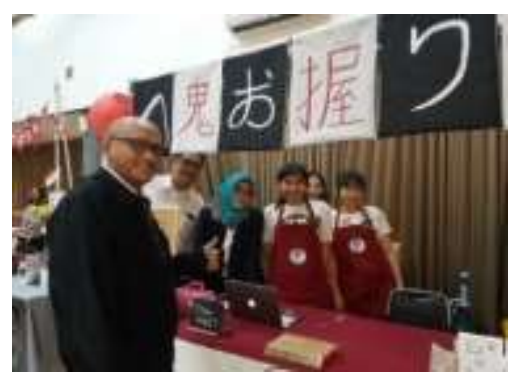

Source : Private Collection

Fig V. One of the booth for culinary project presentation

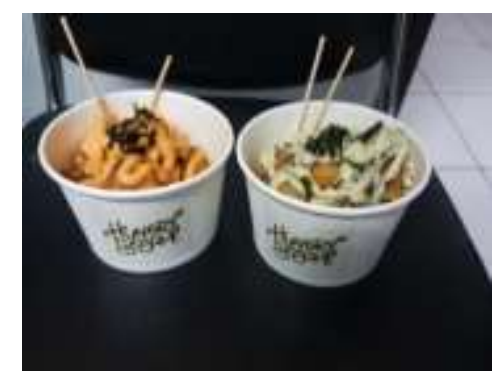

Source : Private Collection

Fig VI. One of some food presentation creations
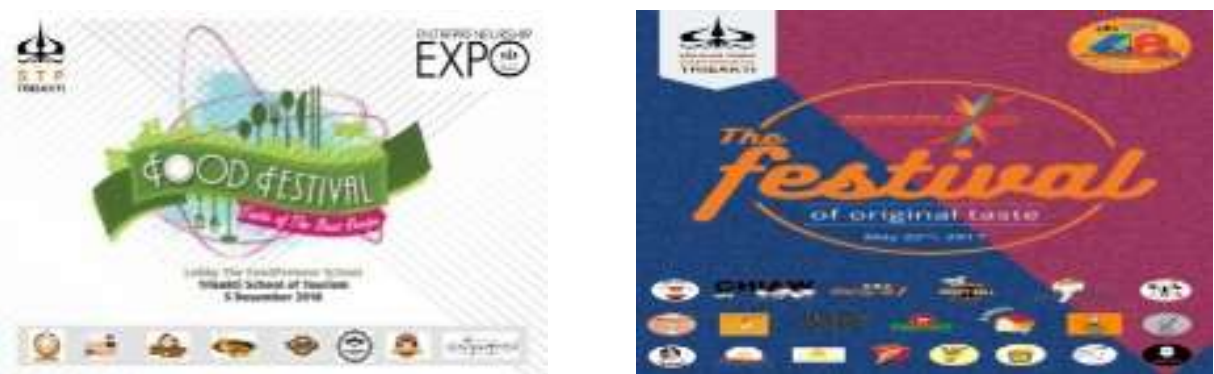

Source : Private Collection

FIG VII. BACKDROP DESIGN ENTREPRENEURSHIP EXPO 

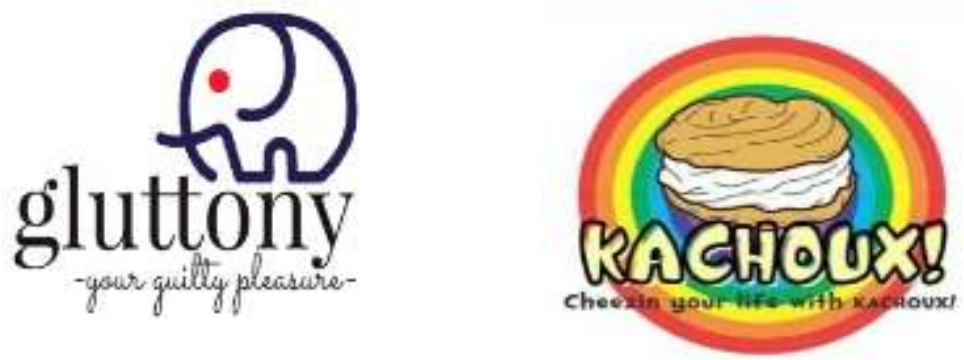

Source : Private Collection

Fig VIII.Some example of logo Design, Student work product

\section{CONCLUSION}

The research show that students of The Trisakti School of Tourism get inspired their from Entrepreneurship Subject which changes their point of view, attitudes, behaviors and perception The result of the positive and linear relationship between entrepreneurship and entrepreneurship interest in the Trisakti School of Tourism is in medium (0.526), and entrepreneurship interest is influenced by entrepreneurship subject $27.7 \%$. It means that students areinterested to start a business after they graduate from college.

\section{REFERENCES}

Darmawan, Ricky. (2011). Pengaruh Minat Belajar dan Perhatian Orang Tua TerhadapPresentas Belajar Siswa KelasTinggi SD Negri 01 WonolopoTahunAjaran 2014/2015. (Unplished Bachelor). Surakarta: UMS

Deputy Human Resources (HR) Kemenkop and UKM, Prakoso BS said, "Young people actually have the desire and ideas for entrepreneurship, but had not the courage" (Kompas.com, January 11,2017),

Djaali. (2008). Psikologi Pendidikan. Jakarta: Bumi Aksara.

Hattab, Hala W. (2014). "Impact of Entrepreneurship Education on Entrepreneurial Intentions of University Students in Egypt", The Journal of Entrepreneurship 23(1) 1-18.

Herawati, Agnes - Academic year : (2010) - Humaniora - Published : 2011 - ISSN : 2087-1236 - Vol : 2 - No : 1 - Page : $445-451$

Herawati,Yusleli. (2011). Langkah Wirausaha Dalam Meningkatkan Dan Mengembangkan Usaha (Studi Kasus Pada Catering Hidayah Palembang). Jurnal Ilmiah Orasi Bisnis-ISSN: 2085-1375 Edisi Ke-VI, November 2011.

Izedonmi, Prince Famous and Okafor, Chinonye. (2010). 'The effect of entrepreneurship education on students' entrepreneurial intentions', Global Journal of Management and Business Research, 10 (6), August: 49-60.

Lestari, B.R dan Trisnadi Wijaya. (2012). Pengaruh Pendidikan Kewirausahaan Terhadap Minat Berwirausaha Mahasiswa Di STIE MDP, STMIK MDP, Dan STIE MUSI. Forum Bisnis dan Kewirausahaan. Jurnal Ilmiah STIE MDP. Vol. 1 No. 02, pp: 112-119.

Lieli,Suharti. (2011). Faktor- Faktor-Faktor yang Berpengaruh Terhadap Niat Kewirausahaan (Entrepreneurial Intention) (Studi Terhadap Mahasiswa Universitas Kristen Satya Wacana, Salatiga), Jurnal Manajemen dan Kewirausahaan. Vol 13. Nomor 2 (2011). ISSN.1411-1438 (online), ISSN.2388-8236 (Print)

Notoatmodjo, Soekidjo. (2012). Promosi Kesehatan dan Perilaku Pendidikan. Jakarta. Rineka Cipta h. $131-207$

Sevilla, Consuelo G. et. al (2007). Research Methods. Rex Printing Company. Quezon City.

Siregar, Sofyan. (2011). Statistika Deskriptif Untuk Penelitian. Jakarta: PT. Raja Grafindo Persada.

Siswadi, Yudi. (2013). Analisis Faktor Internal, Faktor Eksternal Dan Pembelajaran Kewirausahaan Yang Mempengaruhi Minat Mahasiswa Dalam Berwirausaha. Jurnal Manajemen \& Bisnis. Vol 13, No. 01, pp: 1-17. 
Soepardi, Hanni Sofia.(2015). Pemerintah luncurkan paket kebijakan pengembangan wirausaha. http://www.antaranews.com/berita/484788/pemerintah-luncurkan-paket-kebijakan-

pengembangan-wirausaha. Retrieved July 102017.

Sugiyono, (2014), Metode Penelitian Pendidikan, Jakarta : Alfabeta,

Varblane, U. and Mets, T. (2010). Entrepreneurship Education in The Higher Education Institutions (HEIs) of Post-Communist European Countries. Journal of Enterprising Communities: People and Place in The Global Economy, 4 (3), 204-219.

Widoyoko, Eko Putro. (2012). Teknik Penyusunan Instrumen Peneli tian.Yogyakarta: Pustaka Pelajar 